Original research article

\title{
Synergism between WLBU2 peptide and antibiotics against methicillin-resistant Staphylococcus aureus and extended- spectrum beta-lactamase-producing Enterobacter cloacae
}

\author{
Lina Elsalem ${ }^{1 *}$, Suhaila Al Sheboul ${ }^{2}$, Ayat Khasawneh 1, 3 \\ ${ }^{1}$ Jordan University of Science and Technology, Faculty of Medicine, Department of Pharmacology, Irbid, Jordan \\ 2 Jordan University of Science and Technology, Faculty of Applied Medical Sciences, Department of Medical Laboratory Sciences, Irbid, Jordan \\ ${ }^{3}$ The Jordanian Royal Medical Services, Department of Clinical Pathology and Microbiology, Amman, Jordan
}

\begin{abstract}
Infections caused by Methicillin-Resistant Staphylococcus aureus (MRSA) and Extended-Spectrum Beta-Lactamase (ESBL) producing Enterobacter cloacae are considered as major therapeutic challenge due to their multidrug-resistant (MDR) phenotype against conventional antibiotics. WLBU2 is an engineered cationic peptide with potent antimicrobial activity. This in-vitro study aimed to evaluate the effects of WLBU2 against clinical isolates of the aforementioned bacteria and assess whether synergistic effects can be achieved upon combination with conventional antibiotics. The minimum inhibitory concentrations (MICs) of antimicrobial agents against bacterial clinical isolates ( $n=30$ /strain) were determined using the microbroth dilution assay. The minimum bactericidal concentrations (MBCs) of WLBU2 were determined from microbroth dilution (MICs) tests by subculturing to agar plates. MICs of WLBU2 were evaluated in the presence of physiological concentrations of salts including $\mathrm{NaCl}, \mathrm{CaCl}_{2}$ and $\mathrm{MgCl}_{2}$. To identify bacterial resistance profile, $\mathrm{MRSA}$ were treated with Oxacillin, Erythromycin and Vancomycin, while Ceftazidime, Ceftriaxone, Ciprofloxacin and Imipenem were used against Enterobacter cloacae. Combination treatments of antibiotics and sub-inhibitory concentrations of WLBU2 were conducted when MICs indicated intermediate/resistant susceptibility. The MICs/MBCs of WLBU2 were identical for each respective bacteria with values of $0.78-6.25 \mu \mathrm{M}$ and 1.5-12.5 $\mu \mathrm{M}$ against MRSA and Enterobacter cloacae, respectively. WLBU2 was found as salt resistant. Combination treatment showed that synergistic and additive effects were achieved in many isolates of MRSA and Enterobacter cloacae. Our data revealed that WLBU2 is a potent peptide with bactericidal activity. In addition, it demonstrated the selective advantage of WLBU2 as a potential therapeutic agent under physiological solutions. Our findings also support the combination of WLBU2 and conventional antibiotics with potential application for treatment of resistant bacteria.
\end{abstract}

Keywords: Antimicrobial peptide; Combination treatment; Resistant bacteria; Salt sensitivity; Synergism; WLBU2

\section{Highlights:}

- WLBU2 has potent bactericidal effects against MRSA and ESBL producing Enterobacter cloacae.

- WLBU2 is a salt resistant antimicrobial peptide.

- WLBU2 potentiates the effect of conventional antibiotics against resistant bacteria.

- Combination of WLBU2 and antibiotics provides potential application for treatment of resistant bacteria in clinical settings.

\begin{abstract}
Abbreviations:
AMPs - Antimicrobial Peptides; AMR - Antimicrobial Resistance; ATCC - American Type Culture Collection; CLSI - Clinical and Laboratory Standards Institute; ESBL - Extended-Spectrum Beta-Lactamase; FIC $_{\text {Index }}$ - Fractional Inhibitory Concentration Index; HPLC - High-Performance Liquid Chromatography; I - Intermediate susceptibility; ID - Identifier; MRSA - Methicillin-Resistant Staphylococcus aureus; MBCs - Minimum Bactericidal Concentrations; MICs - Minimum Inhibitory Concentrations; MHA - MuellerHinton Agar; MHB - Mueller-Hinton Broth; MDR - Multidrug-Resistant; PF - Potentiation Factor; R - Resistant susceptibility; $S$ - Susceptible.
\end{abstract}

\section{Introduction}

Antimicrobial resistance (AMR) is considered as a major health threat for public health systems around the world (Ferri et al., 2017). It has reached an alarming level since it is significantly associated with high morbidity and mortality rates (Prestinaci et al., 2015). In addition, AMR is well recognized to be associated with increasing health care costs (Dadgostar, 2019).

Methicillin-Resistant Staphylococcus aureus (MRSA) and Extended-Spectrum Beta-Lactamase (ESBL) producing Enterobacteriaceae are recognized as serious therapeutic challenge for

\footnotetext{
* Corresponding author: Lina Elsalem, Jordan University of Science and Technology, Faculty of Medicine, Department of Pharmacology, Irbid 22110, Jordan; e-mail: Imelsalem@just.edu.jo http://doi.org/10.32725/jab.2021.001

Submitted: 2020-09-03 • Accepted: 2021-01-04 • Prepublished online: 2021-01-18

J Appl Biomed 19/1: 14-25 • EISSN 1214-0287 • ISSN 1214-021X

(C) 2021 The Authors. Published by University of South Bohemia in České Budějovice, Faculty of Health and Social Sciences.

This is an open access article under the CC BY-NC-ND license.
} 
treatment of infections during the 21st century due to their multidrug-resistant (MDR) phenotype (Donkor and Codjoe, 2019). MRSA is resistant to all beta-lactam antibiotics and some strains are also resistant to other conventional antibiotics including Macrolides and Fluoroquinolones (Stefani and Goglio, 2010). In comparison, ESBL producing Enterobacteriaceae are resistant to third generation Cephalosporins (Ceftriaxone and Ceftazidime) and Monobactams (Coque et al., 2008).

Conventional antibiotics have limited therapeutic efficacy in providing treatment for MDR bacteria. Therefore, new strategies were developed to overcome AMR (Chellat et al., 2016). Antimicrobial peptides (AMPs) have been extensively studied as potential agents with lower incidence of AMR (Sinha and Shukla, 2019). Most AMPs are cationic peptides with the ability to kill and/or inhibit bacterial growth (Kohn et al., 2018). AMPs have been suggested to bind the bacterial cell membrane and cause disruption of the lipids components (Sani and Separovic, 2016). This is usually induced by electrostatic interactions between amino acids within the peptide (positive charge) and the lipids component (negative charge) of bacterial cell membrane, resulting in bactericidal effect ( $\mathrm{Li}$ et al., 2017).

Recently, the effects of synthetic AMPs, either alone or in combination with conventional antibiotics, have been investigated against many bacteria including MDR strains with biofilm formation ability (Deslouches et al., 2005a; Swedan et al., 2019). WLBU2 is an engineered cationic peptide that contains 24 amino acids including 13 arginine (R), 8 valine $(V)$ and 3 tryptophan (W) residues in the hydrophobic face separated from each other by at least 7 amino acids (Deslouches et al., 2005b). The amino acid sequence is (RRWVRRVRRWVRRVVRVVRRWVRR) (Swedan et al., 2019). Results from in-vitro and animal investigations revealed the potency of WLBU2 against different types of microorganisms including bacteria and diverse Candida species (Deslouches et al., 2008; Lin et al., 2018; Swedan et al., 2019). Preclinical studies on infections caused by Pseudomonas aeruginosa described WLBU2 as a salt resistant with potent inhibitory effects against bacterial growth and biofilm formation as well as induction of protective proinflammatory responses (Chen et al., 2018; Deslouches et al., 2005a; Lashua et al., 2016; Paranjape et al., 2013). The antibacterial potency of WLBU2 was reported against oral microorganisms (Streptococcus gordonii, Fusobacterium nucleatum, and Porphyromonas gingivalis) (Novak et al., 2007). In addition, WLBU2 had bactericidal activity against Francisella tularensis, Yersinia pestis and Burkholderia pseudomallei, which are described as highly pathogenic bacteria (Abdelbaqi et al., 2016). Recently, WLBU2 has been shown to eliminate pneumonia and MRSA superinfection during influenza as well as antibiotic resistant surgical implant biofilms caused by Staphylococcus aureus and MRSA (Mandell et al., 2017; Rich et al., 2016). In addition, it has been found to be very effective in preventing ESKAPE (Enterococcus faecium, Staphylococcus aureus, Klebsiella pneumoniae, Acinetobacter baumannii, Pseudomonas aeruginosa, Enterobacter cloacae) and Escherichia coli pathogen' biofilm formation and attachment (Lin et al., 2018).

Based on the aforementioned studies, WLBU2 appears as a potent broad-spectrum AMP with potential therapeutic effects against highly pathogenic infections. However, only few studies are available regarding the combination of WLBU2 and conventional antibiotics. Recent results have revealed synergistic effects upon combination treatment of WLBU2 with antibacterial agents against biofilms of MDR Acinetobacter baumannii and Klebsiella pneumonia (Swedan et al., 2019).
Accordingly, this in-vitro study aimed to investigate the antimicrobial effects of WLBU2 against clinical isolates of MRSA and ESBL producing Enterobacter cloacae, and to evaluate whether synergistic effects can be obtained using combination treatment between WLBU2 and conventional antibiotics against MRSA and ESBL producing Enterobacter cloacae.

\section{Materials and methods}

\section{Ethical statement}

The study was approved by Jordan University of Science and Technology (JUST) and the Jordanian Royal Medical Services (JRMS) Research Committees and the Institutional Review Boards (IRB) - approval number 8/118/2018 and 5/2018 from aforementioned institutes, respectively. However, this study only involves bacteria isolated from wound infections for routine culture and sensitivity testing; hence patient consent was not needed.

\section{Bacterial strains}

Sixty clinical isolates of MRSA $(n=30)$ and ESBL producing Enterobacter cloacae $(n=30)$ were utilized in this study. They were isolated from clinical samples of wound infections and stored at $-80{ }^{\circ} \mathrm{C}$ in microbiology laboratories of four major hospitals belonging to the JRMS. Reference collection isolates of Staphylococcus aureus subspecies aureus (BAA25923), MRSA (BAA1720), Enterobacter cloacae (BAA13047) and MDR Enterobacter cloacae (BAA2468) were obtained from the American Type Culture Collection (ATCC, Manassas, VA, USA).

\section{Identification tests of MRSA strains}

The identity of ATCC Staphylococcus aureus, ATCC MRSA and all MRSA clinical isolates were confirmed by the biochemical tests including Indole (Negative), Motility (non-motile), Urease (Positive), Citrate (Positive) and Gram Staining (appear as grape-like cluster), Catalase test (Positive) and Coagulase test (Positive). Strains were also subjected to Oxacillin and Cefoxitin disc diffusion test using $30 \mu \mathrm{g}$ discs as described in the Clinical and Laboratory Standards Institute (CLSI) guidelines (CLSI, 2017). Herein, we focused on Cefoxitin testing, which gives more reliable and accurate results than Oxacillin. Identification and susceptibility tests were also confirmed by VITEK 2 Technology (Biomerieux, Durham, USA).

\section{Identification tests of Enterobacter cloacae and detection of ESBL production}

The identity of ATCC Enterobacter cloacae and all ESBL producing Enterobacter cloacae clinical isolates were confirmed by biochemical tests including Indole (Negative), Motility (Motile), Urease (Negative), Citrate (Positive) and Gram Staining (rodshaped), Catalase test (Positive). Strains were also subjected to ESBL disc screening as described in CLSI guidelines (CLSI, 2017). VITEK 2 Technology was applied to confirm identification and susceptibility tests.

\section{Conventional antibiotics}

To perform susceptibility tests. Oxacillin, Erythromycin and Vancomycin were used against Staphylococcus aureus and MRSA, while Ceftazidime, Ceftriaxone, Ciprofloxacin and Imipenem were utilized against ESBL producing Enterobacter cloacae. The choices of antimicrobial agents were made based on the previous publications (Huang et al., 2014; Kshetry et al., 2016; Majidpour et al., 2017; Mohamed et al., 2014; Rooney et al., 2009; Y1ld1z et al., 2014). All conventional antibiotics were obtained from Cayman Chemicals (Ann Arbor, MI, USA). 


\section{WLBU2 peptide}

WLBU2 was synthesized by GL Biochem (Minhang Qu, Shanghai Shi, People's Republic of China). The synthesized peptide with a molecular weight of $\sim 3400 \mathrm{~g} / \mathrm{mol}$ was characterized and purified by the manufacturer using High-performance liquid chromatography (HPLC) and mass spectrometry with purity of $96.13 \%$. Fig. A and Fig. B (Suppl.) show the HPLC and spectra information, respectively, as provided by the manufacturer.

\section{Antibacterial assays}

Minimum inhibitory concentrations (MICs) of antimicrobial agents were evaluated using the microbroth dilution technique in Mueller-Hinton broth (MHB, Oxoid, Basingstoke, Hampshire, UK) with an initial inoculum of $10^{6} \mathrm{CFU} / \mathrm{ml}$ cells in non-treated 96-wells microtiter plates as described previously (Mohamed et al., 2014). To characterize the bacterial drug resistance profile, strains were treated with twofold serial dilutions of conventional antibiotics in accordance with CLSI guidelines (CLSI, 2017). Regarding WLBU2, $50-0.098 \mu \mathrm{M}$ serial dilutions were used for treatment. Plates were incubated aerobically overnight at $37^{\circ} \mathrm{C}$. The MIC was interpreted as the lowest concentration of peptide or antibiotic that completely inhibited the visible growth of bacteria (Mohamed et al., 2014). MIC was determined by measuring the absorbance $\mathrm{OD}_{600}$ using an Epoch ELISA plate reader (BioTek, Winooski, VT, USA). Regarding the MIC values of conventional antibiotics, interpretation was done according to CLSI guidelines (CLSI, 2017) as summarized in Table A (Suppl.). Each agent was tested in triplicate in at least two independent experiments. Sterile MHB was utilized as negative control and bacteria alone without the peptide/antibiotic served as positive controls.

Regarding the treatment with WLBU2 at different concentrations, bacterial growth curves were prepared by plotting WLBU2 concentration at the $\mathrm{x}$-axis and the percentage of bacterial survival on the $y$-axis. Percentages of survival were expressed as percentages of mean absorbance of $\mathrm{OD}_{600}$ for treated bacteria with respect to control (untreated bacteria).

The minimum bactericidal concentrations (MBCs) of WLBU2 which needed to kill $\geq 99.9 \%$ of bacteria were determined by seeding $10 \mu \mathrm{l}$ from wells demonstrating no visible growth (three wells with MIC concentration and higher) on Mueller-Hinton Agar (MHA, Oxoid, Basingstoke, Hampshire, UK) plates as described previously (Swedan et al., 2019). Plates were incubated for $24 \mathrm{~h}$ at $37^{\circ} \mathrm{C}$ to count viable bacteria.

\section{Antibacterial activity of WLBU2 in presence of salts}

To assess the activity of WLBU2 in the presence of salt environment, the MIC was determined using the microbroth dilution assay as described above, except that fixed concentrations of different salts were added to growth media as described previously (Mohamed et al., 2014). These included $\mathrm{NaCl}$ (150 mM, $100 \mathrm{mM}, 50 \mathrm{mM}, 25 \mathrm{mM}), \mathrm{CaCl}_{2}(5 \mathrm{mM}, 2.5 \mathrm{mM})$, and $\mathrm{MgCl}_{2}$ ( $2 \mathrm{mM}, 1 \mathrm{mM})$. Experiments were carried out against ATCC bacteria strains as well as selected clinical isolates of MRSA and resistant Enterobacter cloacae.

\section{Combination treatment between WLBU2 and conventional antibiotics}

Combination treatment of WLBU2 and conventional antibiotics was conducted by the combination assay as described previously (Mohamed et al., 2014; 2016). Experiments were carried out if the MIC values of antibiotics indicated intermediate or resistant susceptibility. Two-fold serial dilutions of antibiotics were tested in the presence of a fixed concentration of WLBU2 (equal to $25 \%$ of WLBU2' MIC for each respective isolate) (Mohamed et al., 2014; 2016). Based on the obtained data, the isobolograms of combined action were plotted and the fractional inhibitory concentration index $\left(\right.$ FIC $\left._{\text {Index }}\right)$ was calculated according to the following equation: $\mathrm{FIC}_{\text {Index }}=\mathrm{MIC}$ (antibiotic in combination) $\backslash \mathrm{MIC}$ (antibiotic alone) +0.25 . $\mathrm{FIC}_{\text {Index }}$ was interpreted as following: $\mathrm{FIC}_{\text {Index }} \leq 0.5$ : synergistic, $0.5<\mathrm{FIC}_{\mathrm{In}-}$ dex $<1$ : additive, $1 \leq \mathrm{FIC}_{\text {Index }}<4.0$ : indifferent, or $\mathrm{FIC}_{\text {Index }} \geq 4.0$ : antagonistic as described previously (Wu et al., 2017). Potentiation factor which represents fold reduction in antibiotic' MIC in the presence of $25 \%$ of WLBU2' MIC relative to the antibiotic' MIC in the absence of WLBU2 was also calculated (Corbett et al., 2017).

\section{Results}

\section{Drug resistance profile of planktonic bacteria}

MIC values of conventional antibiotics against MRSA clinical isolates, ESBL producing Enterobacter cloacae and ATCC strains are summarized in Table 1 . Results of MIC using the microbroth dilution technique indicate that all MRSA clinical isolates are resistant to Oxacillin with MICs range of 4-16 $\mu \mathrm{g} / \mathrm{ml}$. However, they were sensitive to Vancomycin with MICs range of $0.125-1 \mu \mathrm{g} / \mathrm{ml}$. Regarding Erythromycin, out of the 30 investigated isolates, 15 were sensitive $(50 \%$, MICs $\leq 0.5 \mu \mathrm{g} / \mathrm{ml})$, 12 were intermediate $(40 \%, \mathrm{MICs}=1-4 \mu \mathrm{g} / \mathrm{ml})$ and 3 were resistant $(10 \%, \mathrm{MICs} \geq 8 \mu \mathrm{g} / \mathrm{ml})$. The ATCC bacteria BAA1720 (MRSA) was resistant to Oxacillin (MIC $=8 \mu \mathrm{g} / \mathrm{ml})$ and Erythromycin (MIC $=8 \mu \mathrm{g} / \mathrm{ml})$, but sensitive to Vancomycin (MIC $=0.5 \mu \mathrm{g} / \mathrm{ml}$ ). The ATCC BAA25923 (Staphylococcus aureus) was sensitive to the three conventional antibiotics (Oxacillin, Erythromycin and Vancomycin).

The 30 investigated clinical isolates of ESBL producing Enterobacter cloacae were resistant to Ceftazidime and Ceftriaxone with MICs of 128 and $64 \mu \mathrm{g} / \mathrm{ml}$, respectively. Of note, these isolates showed co-resistance to Ciprofloxacin with MICs of $64 \mu \mathrm{g} / \mathrm{ml}$. On the other hand, all clinical isolates were sensitive to Imipenem with MICs range $0.06-0.13 \mu \mathrm{g} / \mathrm{ml}$. The ATCC BAA2468 (MDR) was resistant to the four conventional antibiotics, while the ATCC BAA13047 was resistant to Imipenem and sensitive to Ceftazidime, Ceftriaxone and Ciprofloxacin.

\section{MIC and MBC of WLBU2 against planktonic bacteria}

The bacterial growth curves of MRSA and Enterobacter cloacae strains upon treatment with different concentrations of WLBU2 are shown in Fig. 1A and B, respectively. The MIC and $\mathrm{MBC}$ values for WLBU2 against bacterial clinical isolates and ATCC strains are summarized in Table 2. The MIC and $\mathrm{MBC}$ values were identical for each respective isolate and ATCC strains. MIC/MBC values for MRSA isolates were in the range of $0.78-6.25 \mu \mathrm{M}$ (median $=3.13 \mu \mathrm{M}$ ). For ESBL producing Enterobacter cloacae isolates, $\mathrm{MIC} / \mathrm{MBC}$ values were in the range of $1.56-12.5 \mu \mathrm{M}$ (median $=3.13 \mu \mathrm{M})$.

\section{WLBU2 is salt resistant}

Selected panel of MRSA and ESBL producing Enterobacter cloacae clinical isolates as well as ATCC strains were treated with WLBU2 in the presence of different concentrations of salts $\left(\mathrm{NaCl}, \mathrm{MgCl}_{2}\right.$ and $\mathrm{CaCl}_{2}$ ). As indicated in Table 3, WLBU2 was considered as salt resistant since the MIC values were identical for respective isolates even in the presence of salts at physiological concentrations. 
Table 1. MIC values of conventional antibiotics against planktonic bacteria

\begin{tabular}{|c|c|c|}
\hline \multicolumn{3}{|c|}{ MRSA clinical isolates and Staphylococcus aureus ATCC strains } \\
\hline Antibiotic & MIC ( $\mu \mathrm{g} / \mathrm{ml})$ (susceptibility) & Bacteria ID \\
\hline \multirow{4}{*}{ Oxacillin } & $1(S)$ & BAA25923 \\
\hline & $4(\mathrm{R})$ & $3,7,13,25,27,28$ \\
\hline & $8(\mathrm{R})$ & $1,2,4-6,8-11,14,15,20-24,26,29,30$, BAA 1720 \\
\hline & $16(\mathrm{R})$ & $12,16-19$ \\
\hline \multirow{6}{*}{ Erythromycin } & $0.25(S)$ & $2,3,7,9,13,14,18,19,21,22,24,27,28,30$, BAA25923 \\
\hline & $0.5(\mathrm{~S})$ & 23 \\
\hline & $1(\mathrm{I})$ & $12,16,20$ \\
\hline & $2(\mathrm{I})$ & $1,4,10,15,25,29$ \\
\hline & $4(\mathrm{I})$ & $5,6,11$ \\
\hline & $8(\mathrm{R})$ & $8,17,26$, BAA1720 \\
\hline \multirow{4}{*}{ Vancomycin } & $0.13(S)$ & $2,3,8,12,13,16,18-20,22-24,26-28,30$ \\
\hline & $0.25(S)$ & $4,5,7,9.25$ \\
\hline & $0.5(\mathrm{~S})$ & $1,6,10,11,14,17,21,29$, BAA1720, BAA25923 \\
\hline & $1(S)$ & 15 \\
\hline
\end{tabular}

ESBL producing Enterobacter cloacae clinical isolates and ATCC strains

\begin{tabular}{lll}
\hline Antibiotic & MIC $(\mu \mathrm{g} / \mathrm{ml})$ (susceptibility) & Bacteria ID \\
\hline \multirow{2}{*}{ Ceftazidime } & $1(\mathrm{~S})$ & BAA13047 \\
& $128(\mathrm{R})$ & $1-30$, BAA2468 \\
\hline \multirow{3}{*}{ Ceftriaxone } & $1(\mathrm{~S})$ & BAA13047 \\
& $64(\mathrm{R})$ & $1-30$ \\
Ciprofloxacin & $128(\mathrm{R})$ & BAA2468 \\
\hline & $0.25(\mathrm{~S})$ & BAA13047 \\
\multirow{2}{*}{ Imipenem } & $64(\mathrm{R})$ & $1-30$, BAA2468 \\
& $0.06(\mathrm{~S})$ & $8-13,16-20,22,24,25,29$ \\
& $0.13(\mathrm{~S})$ & $1-7,14,15,21,23,26-28,30$ \\
& $4(\mathrm{R})$ & BAA13047 \\
\hline
\end{tabular}
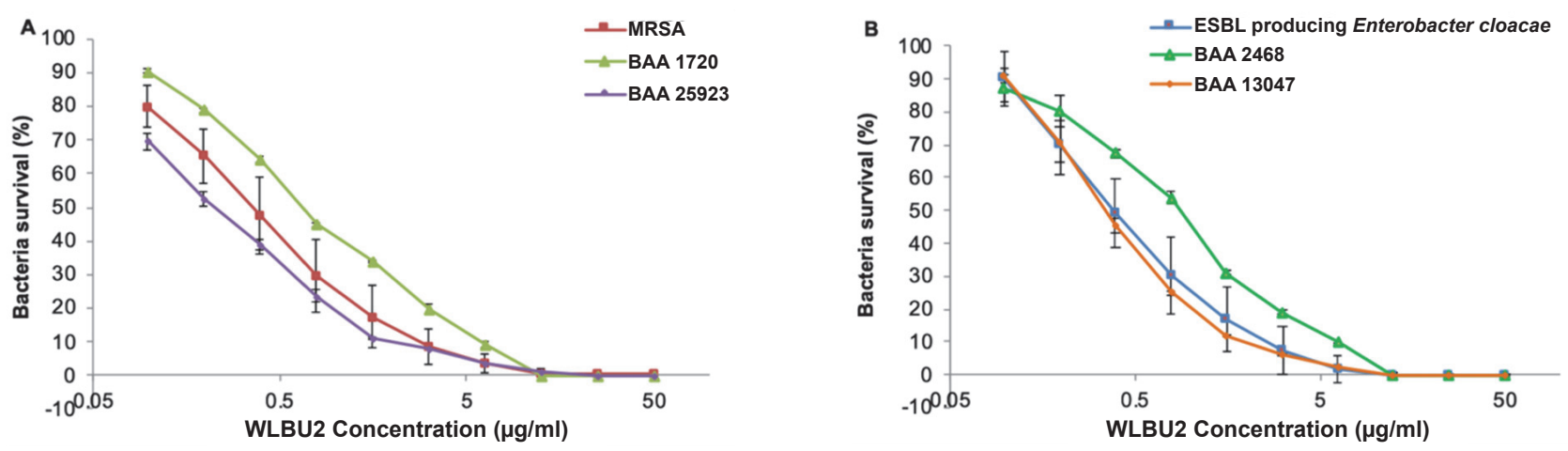

Fig. 1. Growth curves of planktonic bacteria upon treatment with WLBU2. (A) MRSA clinical isolates and ATCC strains and (B) Enterobacter cloacae clinical isolates and ATCC strains. Different concentrations of WLBU2 were tested in triplicate in at least two independent experiments. Percentages of survival were expressed as percentages of mean absorbance of $\mathrm{OD}_{600}$ for treated bacteria normalized to control (untreated bacteria). Points and error bars represent the mean and standard deviation, respectively. For clinical isolates, the mean is for the 30 clinical isolates.

Table 2. The minimum inhibitory/minimum bactericidal concentration (MIC/MBC) values for WLBU2 against planktonic bacteria

\begin{tabular}{llr}
\hline Bacteria strains & Bacteria ID & WLBU2 MIC/MBC $(\mu \mathrm{M})$ \\
\hline & 4 & 0.78 \\
MRSA clinical isolates and Staphylococcus aureus & $3,7,11,13,22-24,30$ & 1.56 \\
ATCC strains & $2,8-10,12,14-19,25,28,29$, BAA25923 & 3.13 \\
& $1,5,6,20,21,26,27$, BAA1720 & 6.25 \\
\hline & $4,5,8,15,19$ & 1.56 \\
Enterobacter cloacae clinical isolates and ATCC & $2,3,6,7,9-14,16-18,20,21,24,27-30$, BAA13047 & 3.13 \\
strains & $1,23,25,26$, BAA2468 & 6.25 \\
& 22 & 12.5 \\
\hline
\end{tabular}


Table 3. Minimum inhibitory concentration $(\mu \mathrm{M})$ of WLBU2 against planktonic bacteria in the presence of physiological concentrations of salts $\left(\mathrm{NaCl}, \mathrm{CaCl}_{2}\right.$ and $\left.\mathrm{MgCl}_{2}\right)$

\begin{tabular}{|c|c|c|c|c|c|}
\hline Bacteria strain & Bacteria ID & No salts & $\begin{array}{c}\mathrm{NaCl} \\
(25,50,100,150 \mathrm{mM})\end{array}$ & $\begin{array}{c}\mathrm{CaCl}_{2} \\
(2.5,5 \mathrm{mM})\end{array}$ & $\begin{array}{c}\mathrm{MgCl}_{2} \\
(1,2 \mathrm{mM})\end{array}$ \\
\hline \multirow{4}{*}{$\begin{array}{l}\text { MRSA clinical isolates and } \\
\text { Staphylococcus aureus ATCC } \\
\text { strains }\end{array}$} & 4 & 0.78 & 0.78 & 0.78 & 0.78 \\
\hline & 11 & 1.56 & 1.56 & 1.56 & 1.56 \\
\hline & 12, BAA25923 & 3.13 & 3.13 & 3.13 & 3.13 \\
\hline & 1, BAA1720 & 6.25 & 6.25 & 6.25 & 6.25 \\
\hline \multirow{4}{*}{$\begin{array}{l}\text { Enterobacter cloacae clinical } \\
\text { isolates and ATCC strains }\end{array}$} & 5 & 1.56 & 1.56 & 1.56 & 1.56 \\
\hline & 7, BAA13047 & 3.13 & 3.13 & 3.13 & 3.13 \\
\hline & 1, BAA2468 & 6.25 & 6.25 & 6.25 & 6.25 \\
\hline & 22 & 12.5 & 12.5 & 12.5 & 12.5 \\
\hline
\end{tabular}

\section{Combination treatment of WLBU2 with conventional antibiotics against planktonic bacteria}

Combination treatments of conventional antibiotics and WLBU2 at its sub-inhibitory concentration (25\% of WLBU2' MIC value of respective strain) were carried out if the MIC values of antibiotics indicated resistant or intermediate susceptibility.
Regarding MRSA clinical isolates (Table 4), combination of WLBU2 peptide with Oxacillin resulted in a 2-fold reduction of Oxacillin's MIC in 14/30 (46.7\%) clinical isolates with $\mathrm{FIC}_{\text {Index }}=0.75$. Of note, isolate ID 27 has shifted from Oxacillin resistance to susceptible upon combination. All remaining isolates ( $n=16 / 30,53.3 \%$ ) as well as BAA1720 (MRSA) showed no change in the MIC of Oxacillin upon combination

Table 4. Results of synergism testing between sub-inhibitory WLBU2 concentrations and conventional antibiotics against MRSA clinical isolates and ATCC strain

\begin{tabular}{|c|c|c|c|c|c|c|}
\hline \multirow[t]{2}{*}{$\begin{array}{l}\text { Conventional } \\
\text { antibiotic }\end{array}$} & \multirow[t]{2}{*}{ Isolate ID } & \multirow[t]{2}{*}{$\begin{array}{c}25 \% \text { of WLBU2 } \\
\text { MIC }(\mu \mathrm{M})\end{array}$} & \multicolumn{2}{|c|}{$\begin{array}{l}\text { MIC of conventional antibiotic } \\
\qquad(\mu \mathrm{g} / \mathrm{ml})\end{array}$} & \multirow[t]{2}{*}{$\mathrm{PF}$} & \multirow[t]{2}{*}{ FIC $_{\text {Index }}$} \\
\hline & & & Alone & Combination & & \\
\hline \multirow{12}{*}{ Oxacillin } & 4,10 & 0.2 & \multirow{4}{*}{8} & \multirow{4}{*}{8} & \multirow{7}{*}{1} & \multirow{7}{*}{1.25} \\
\hline & 23 & 0.39 & & & & \\
\hline & 2,9 & 0.78 & & & & \\
\hline & $1,5,20$, BAA 1720 & 1.56 & & & & \\
\hline & $3,7,13$ & 0.39 & \multirow{2}{*}{4} & \multirow{2}{*}{4} & & \\
\hline & 25,28 & 0.78 & & & & \\
\hline & $16,18,19$ & 0.78 & 16 & 16 & & \\
\hline & $11,22,24,30$ & 0.39 & \multirow{3}{*}{8} & & \multirow{5}{*}{2} & \multirow{5}{*}{0.75} \\
\hline & $8,14,15,29$ & 0.78 & & 4 & & \\
\hline & $6,21,26$ & 1.56 & & & & \\
\hline & 12,17 & 0.78 & 16 & 8 & & \\
\hline & 27 & 1.56 & $4(\mathrm{R})$ & $2(S)$ & & \\
\hline \multirow{14}{*}{ Erythromycin } & 10 & 0.2 & \multirow{2}{*}{2} & \multirow{2}{*}{2} & \multirow{4}{*}{1} & \multirow{4}{*}{1.25} \\
\hline & 15 & 0.78 & & & & \\
\hline & 16 & 0.78 & \multirow{2}{*}{1} & \multirow{2}{*}{1} & & \\
\hline & 20 & 1.56 & & & & \\
\hline & 12 & 0.78 & 1 (I) & $0.5(S)$ & \multirow{8}{*}{2} & \multirow{8}{*}{0.75} \\
\hline & 4 & 0.2 & \multirow{3}{*}{2} & \multirow{3}{*}{1} & & \\
\hline & 25,29 & 0.78 & & & & \\
\hline & 1 & 1.56 & & & & \\
\hline & 11 & 0.39 & \multirow{2}{*}{4} & \multirow{2}{*}{2} & & \\
\hline & 5,6 & 1.56 & & & & \\
\hline & 17 & 0.78 & \multirow{2}{*}{$8(\mathrm{R})$} & \multirow{2}{*}{4 (I) } & & \\
\hline & BAA1720 & 1.56 & & & & \\
\hline & 8 & 0.78 & $8(\mathrm{R})$ & 1 (I) & 8 & 0.375 \\
\hline & 26 & 1.56 & $8(\mathrm{R})$ & 2 (I) & 4 & 0.5 \\
\hline
\end{tabular}


$\left(\mathrm{FIC}_{\text {Index }}=1.25\right)$. According to $\mathrm{FIC}_{\text {Index }}$ described by the previous publication (Wu et al., 2017), it can be concluded that additive effect was achieved in $46.7 \%$ of investigated isolates, while $53.3 \%$ showed indifferent effects. Corresponding isobologram is shown in Fig. 2A.

For combination treatment with Erythromycin, experiments were carried out when MIC indicated resistance $(n=3)$ or intermediate $(n=12)$ susceptibility in total of 15 isolates. Synergistic effects were achieved in 2 resistant isolates $(2 / 15$, $13.3 \%$ ) with $\mathrm{FIC}_{\text {Index }}=0.375$ and 0.5 , as well as 8 and 4 -fold reduction in antibiotic' MICs in isolates ID 26 and 8, respectively. The resistant isolate ID 17 and eight clinical isolates with intermediate susceptibility $(9 / 15,60 \%)$ as well as the BAA1720 (MRSA) showed a 2-fold reduction in antibiotic's MIC with FIC $_{\text {Index }}=0.75$. Of note, MICs of aforementioned isolates and ATCC bacteria indicated intermediate susceptibility upon combination, while isolate ID 12 has shifted from intermediate to susceptible. The remaining isolates $(n=4 / 15$, $26.7 \%$ ) showed no change in the MIC of Erythromycin upon combination $\left(\mathrm{FIC}_{\text {Index }}=1.25\right)$. The results revealed that combination treatment resulted in synergistic and additive effects in $13.3 \%$ and $60 \%$ of investigated isolates, while $26.7 \%$ showed indifferent effects. Fig. 2B represents the isobologram for combination of WLBU2 and Erythromycin.
There were no antagonistic effects observed between the WLBU2 and antibiotics against all MRSA strains tested. Results with calculated values of potentiation factor and $\mathrm{FIC}_{\text {Index }}$ are summarized in Table 4.

Regarding Enterobacter cloacae clinical isolates (Table 5), combination of WLBU2 with Ceftazidime, Ceftriaxone and Ciprofloxacin resulted in synergistic effects in $7 / 30$ (23.3\%), $10 / 30$ (33.3\%) and 10/30 (33.3\%) clinical isolates, respectively, with $\mathrm{FIC}_{\text {Index }} \leq 0.5$. Herein, a 4 -fold reduction in antibiotics' MICs was observed, while 8-fold reduction was demonstrated in Ceftriaxone' MIC in isolate ID 9. In addition, a 2-fold reduction in Ceftazidime, Ceftriaxone and Ciprofloxacin MICs was reported in $17 / 30$ (56.7\%), 16/30 (53.3\%) and 17/30 (56.7\%) clinical isolates, respectively with $\mathrm{FIC}_{\text {Index }}=0.75$ that can indicate additive effects according to the previous publication (Wu et al., 2017). For BAA2468 (MDR) strain, 2-fold reduction in Ceftazidime' MIC was observed upon combination with WLBU2. There were no antagonistic effects observed between the WLBU2 and antibiotics against all Enterobacter cloacae strains tested. Table 5 summarizes the results with calculated values of potentiation factor and $\mathrm{FIC}_{\text {Index }}$. The isobolograms for combination of WLBU2 and the three antibiotics are shown in Fig. 2C-E.

Table 5. Results of synergism testing between sub-inhibitory WLBU2 concentrations and conventional antibiotics against Enterobacter cloacae clinical isolates and ATCC strain

\begin{tabular}{|c|c|c|c|c|c|c|}
\hline \multirow[t]{2}{*}{$\begin{array}{l}\text { Conventional } \\
\text { antibiotic }\end{array}$} & \multirow[t]{2}{*}{ Isolate ID } & \multirow[t]{2}{*}{$\begin{array}{l}25 \% \text { of WLBU2 } \\
\text { MIC }(\mu \mathrm{M})\end{array}$} & \multicolumn{2}{|c|}{$\begin{array}{l}\text { MIC of conventional antibiotic } \\
(\mu \mathrm{g} / \mathrm{ml})\end{array}$} & \multirow[t]{2}{*}{$\mathrm{PF}$} & \multirow[t]{2}{*}{$\mathrm{FIC}_{\text {Index }}$} \\
\hline & & & Alone & Combination & & \\
\hline \multirow{9}{*}{ Ceftazidime } & 5 & 0.39 & \multirow{3}{*}{128} & \multirow{3}{*}{128} & \multirow{3}{*}{1} & \multirow{3}{*}{1.25} \\
\hline & $2,6,9,20$ & 0.78 & & & & \\
\hline & 1 & 1.56 & & & & \\
\hline & 4,8 & 0.39 & \multirow{4}{*}{128} & \multirow{4}{*}{64} & \multirow{4}{*}{2} & \multirow{4}{*}{0.75} \\
\hline & $3,10-14,16-18,21,29$ & 0.78 & & & & \\
\hline & $23,25,26$, BAA2468 & 1.56 & & & & \\
\hline & 22 & 3.13 & & & & \\
\hline & 15,19 & 0.39 & \multirow{2}{*}{128} & \multirow{2}{*}{32} & \multirow{2}{*}{4} & \multirow{2}{*}{0.5} \\
\hline & $7,24,27,28,30$ & 0.78 & & & & \\
\hline \multirow{9}{*}{ Ceftriaxone } & $5,8,19$ & 0.39 & \multirow{2}{*}{64} & \multirow{2}{*}{64} & \multirow{3}{*}{1} & \multirow{3}{*}{1.25} \\
\hline & 7 & 0.78 & & & & \\
\hline & BAA2468 & 1.56 & 128 & 128 & & \\
\hline & 4,15 & 0.39 & \multirow{3}{*}{64} & \multirow{3}{*}{32} & \multirow{3}{*}{2} & \multirow{3}{*}{0.75} \\
\hline & $2,3,10,11,13,16-18,20,21$ & 0.78 & & & & \\
\hline & $1,23,25,26$ & 1.56 & & & & \\
\hline & 22 & 3.13 & \multirow{2}{*}{64} & \multirow{2}{*}{16} & \multirow{2}{*}{4} & \multirow{2}{*}{0.5} \\
\hline & $6,12,14,24,27-30$ & 0.78 & & & & \\
\hline & 9 & 0.78 & 64 & 8 & 8 & 0.375 \\
\hline & $5,8,19$ & 0.39 & 64 & 64 & 1 & 125 \\
\hline & BAA2468 & 1.56 & . & & & \\
\hline & 4,15 & 0.39 & & & & \\
\hline Ciprofloxacin & $2,3,7,10-14,21,27,30$ & 0.78 & 64 & 32 & 2 & 0.75 \\
\hline & $1,23,25,26$ & 1.56 & & & & \\
\hline & $6,9,16-18,20,24,28,29$ & 0.78 & 64 & 16 & 4 & 05 \\
\hline & 22 & 3.13 & 64 & 16 & 4 & 0.3 \\
\hline
\end{tabular}


MRSA

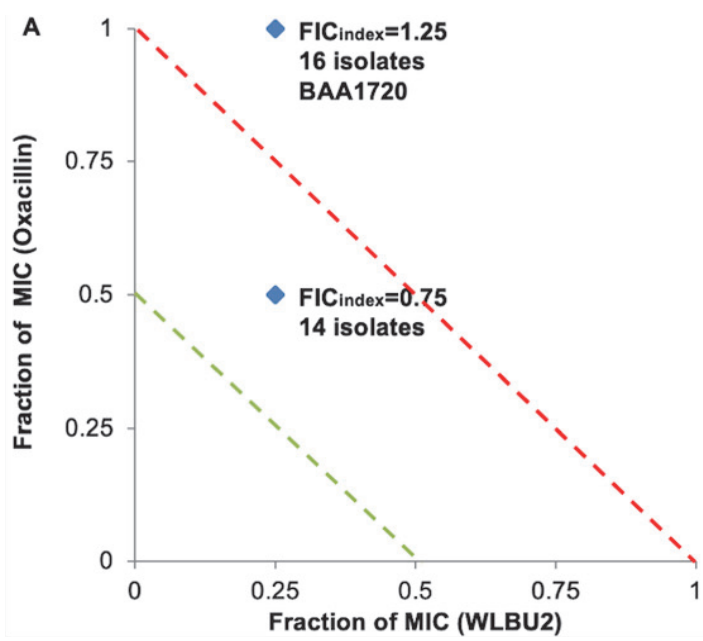

ESBL producing Enterobacter cloacae

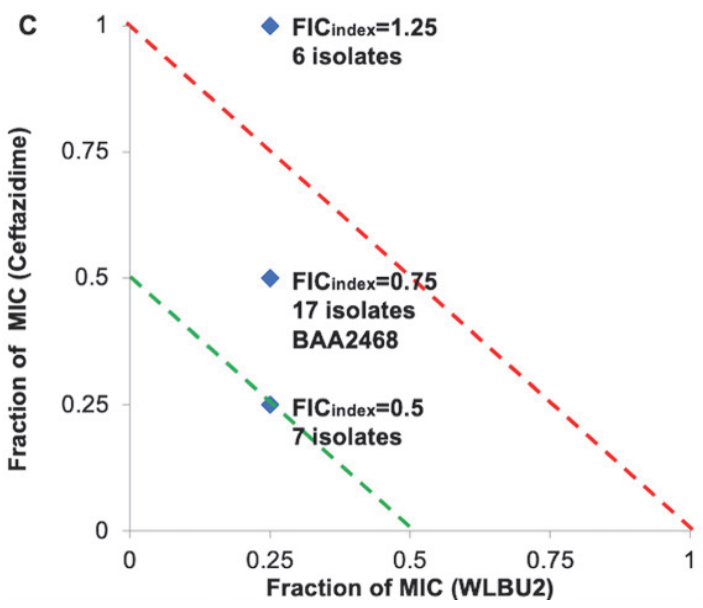

MRSA

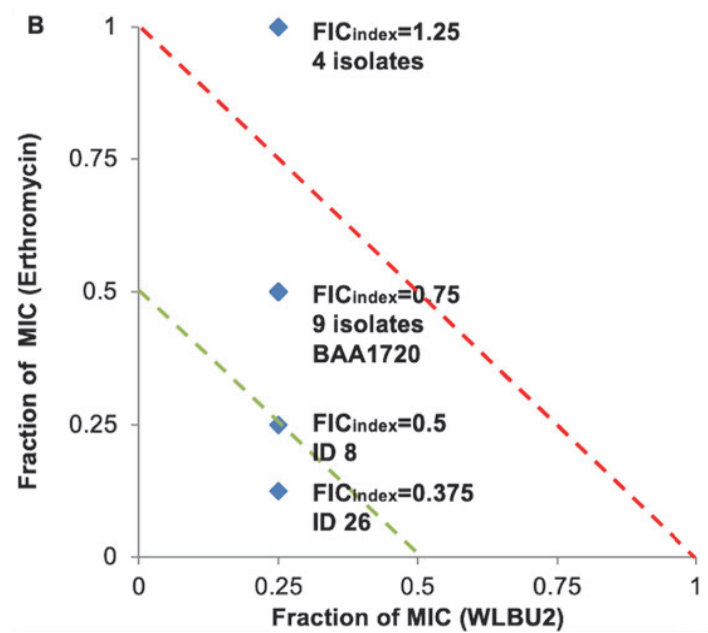

ESBL producing Enterobacter cloacae

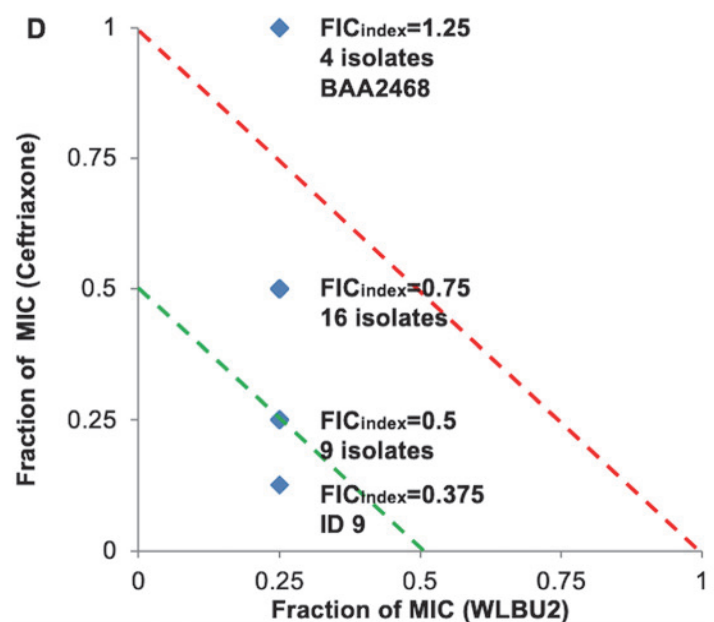

ESBL producing Enterobacter cloacae

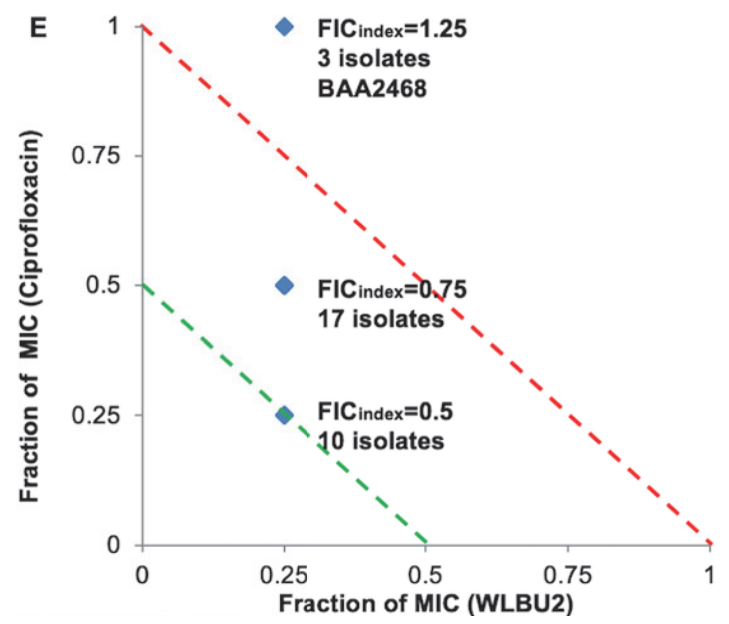

Fig. 2. Combined antibacterial effect of WLBU2 with conventional antibiotics against planktonic bacteria. Isobolograms for combination of WLBU2 with (A) Oxacillin and (B) Erythromycin against MRSA, (C, D and E) Isobolograms for combination of WLBU2 with Ceftazidime, Ceftriaxone and Ciprofloxacin, respectively, against Enterobacter cloacae. Concentrations of antimicrobial agents are given in fractions of their individual minimal inhibitory concentrations (MICs). Points lying on or underneath the green line are considered to be synergistic (FIC $\mathrm{Index}_{\mathrm{B}}$ $\leq 0.5)$. Points between the green and red line are considered additive $\left(0.5<\mathrm{FIC}_{\text {Index }}<1\right)$ and points at or above the red line are considered as

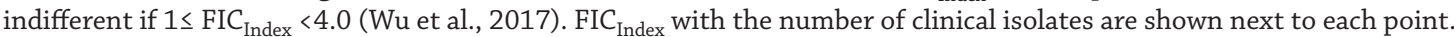




\section{Discussion}

Infections caused by MRSA and ESBL producing Enterobacteriaceae are characterized by being MDR to conventional antibiotics, which is considered as serious therapeutic challenge for treatment of bacterial infections during the 21st century (Donkor and Codjoe, 2019). WLBU2 is one of the newly engineered cationic AMPs with promising antimicrobial activity against different strains of Gram-negative and Gram-positive pathogens, multidrug resistant and biofilm forming bacteria (Swedan et al., 2019). In this in-vitro study, the antimicrobial activity of WLBU2 was evaluated against drug resistant clinical isolates of MRSA and ESBL producing Enterobacter cloacae as little is known about WLBU2 activity against the latter.

Initially, the MIC values of conventional antibiotics were utilized to explore the drug resistance profile of both strains. We found that many of investigated clinical isolates exhibited resistance to various important antibiotic classes including penicillins, macrolides, cephalosporins and fluoroquinolones which were in accordance with previous studies (Blahová et al., 1999; Huang et al., 2014; Kshetry et al., 2016; Majidpour et al., 2017; Mohamed et al., 2014; Rooney et al., 2009; Spanu et al., 2002; Wiener et al., 2016; Yildız et al., 2014). In comparison, MRSA and ESBL producing Enterobacter cloacae clinical isolates were sensitive to Vancomycin and Imipenem, respectively, which was reported by other studies and hence, considered as drug of choice for treatment of infections caused by these strains (Kshetry et al., 2016; Mohammed and Abass, 2019).

We then explored the antibacterial activity of WLBU2 against the clinical isolates and ATCC bacteria strains. It is worth mentioning that little is known about the antibacterial activity of WLBU2 against ESBL producing Enterobacter cloacae. Herein, WLBU2 exhibited strong antibacterial activity against investigated bacteria, with MICs range of 0.78-6.25 $\mu \mathrm{M}$ for MRSA and 1.56-12.5 $\mu \mathrm{M}$ for ESBL producing Enterobacter cloacae. Of note, the MBC values for WLBU2 were found to be identical to the MIC values of respective bacteria, indicating that WLBU2 exhibits bactericidal activity (Tripathi, 2013). The potent antibacterial activity of WLBU2 against both bacteria points to the potential of using WLBU2 as a treatment option for infections caused by pathogenic bacteria that are highly resistant to conventional antibiotics. The exact mechanisms for WLBU2 are yet to be elucidated. However, it was suggested to be mediated by electrostatic interactions between peptide' cationic amino acid residues and the negatively charged lipid molecules on the surface of bacterial targets (Deslouches et al., 2005a). Therefore, the potent activity of WLBU2 may be attributed to the high cationic charge and the increased length of amino acids of WLBU2 (24 residues) (Deslouches et al., 2005a; 2013). Previous studies reported that AMP activity might also be mediated by binding to bacteria DNA (Mohamed et al., 2014). However, limited investigations have been conducted for WLBU2. Only recent findings have revealed that WLBU2 was not able to delay DNA mobility (Swedan et al., 2019).

WLBU2 MIC/MBC values from our investigations are in accordance with previous studies which showed that WLBU2 has fast killing effects with MIC values $\leq 10 \mu \mathrm{M}$ (Deslouches et al., 2013; 2015, Swedan et al., 2019). Findings of our study and others support that WLBU2 has broad spectrum activity with potent bactericidal effect against different isolates that exhibit resistance to various important antibiotic classes.

In this study, we also investigated the antibacterial activity of WLBU2 against all ATCC strains and selected clinical iso- lates in the presence of salts including sodium chloride and divalent cations. This was highly valuable since one of the major drawbacks with the use of AMPs, mainly the natural AMPs, is their limited activity due to inactivation by physiological concentrations of salts (Mohamed et al., 2014). In addition, salt sensitivity might be dependent on the test organism (Deslouches et al., 2005a). Herein, WLBU2 retained its effect when tested under various $\mathrm{NaCl}, \mathrm{CaCl}_{2}$ and $\mathrm{MgCl}_{2}$ concentrations. The ability of WLBU2 to resist the effects of salts provides a selective advantage as potential therapeutics in physiological solutions. This is considered highly important for treatment of infections in conditions with disturbed normal salt homeostasis (Deslouches et al., 2005a). In addition, it suggests that the chemical structure of WLBU2 has been well designed to relatively retain antimicrobial activity in the presence of $\mathrm{NaCl}$ and divalent cations which is considered a major challenge for natural peptides. Previous studies showed that the antibacterial activity of well-studied natural AMPs was substantially reduced under similar conditions (Chu et al., 2013; Turner et al., 1998). In comparison, it was reported that WLBU2 activity against $P$ seudomonas aeruginosa remained unchanged under various $\mathrm{NaCl}, \mathrm{CaCl}_{2}$ and $\mathrm{MgCl}_{2}$ concentrations (Deslouches et al., 2005a), which was also supported by our results.

Recognizing the potent antimicrobial activity of WLBU2, even under salt environments, suggests that it has the potential to be used for treatment of infections caused by resistant bacteria. However, combination therapy is well known to have many advantages (Tyers and Wright, 2019). Upon reviewing the literature, limited evidence is available regarding the combination of WLBU2 and other conventional antibiotics against MRSA or ESBL producing Enterobacter cloacae from clinical isolates being examined. Herein, combination treatment was conducted if MIC values of antibiotic against respective isolate indicated resistant or intermediate susceptibility (Swedan et al., 2019). In this study, WLBU2 potentiated the antibacterial effect of conventional antibiotics with synergistic and additive effects were obtained in many instances of MRSA and ESBL producing Enterobacter cloacae. In addition, there were no antagonistic effects upon combination. According to our knowledge, our study is among the first studies to report evidence of potentiation and synergism upon combination of WLBU2 and conventional antibiotics against examined clinical isolates. This might be a result of increased membrane permeability caused by the action of WLBU2 cationic peptide, which enhanced the penetration of antibiotics toward bacterial cells and thus, improved the drug efficacy and killing effects (Mohamed et al., 2016; Tyers and Wright, 2019). Findings from combination experiments are proof of concept that combination of antimicrobial agents can reduce antibiotic resistance caused by resistant bacteria. Further, it might result in obtaining synergistic effects and thus enhances efficacy (Tyers and Wright, 2019). Advantages of combination treatment may also include broadening the spectrum of antimicrobial coverage and reducing the needed doses of each antimicrobial agent and thus, drug toxicity (Tyers and Wright, 2019).

Our results support synergistic effects reported by previous studies upon combination of AMP such as HPME, HPMA, CAME, CA, DP7 and SPR741 with conventional antibiotics to overcome MDR (Corbett et al., 2017; Deslouches et al., 2015; Gopal et al., 2014; Wu et al., 2017). Only recent study has shown that combination of WLBU2 with Amoxicillin-Clavulanate or Ciprofloxacin for Klebsiella pneumonia, and with Tobramycin or Imipenem for Acinetobacter baumannii, resulted in synergism (Swedan et al., 2019). The combination of WLBU2 and conventional antibiotics appears a promising approach 
with clinical translational potential for treatment of infections caused by resistant MRSA and ESBL producing Enterobacter cloacae.

\section{Conclusions}

Results from this in-vitro study revealed that WLBU2 peptide has a potent antibacterial activity against resistant MRSA and ESBL producing Enterobacter cloacae strains. In addition, WLBU2 demonstrated the selective advantage as a potential therapeutic agent under physiological solutions. Further, we reported synergism upon combination of WLBU2 with conventional antibiotics which points to potential clinical application of using this approach for treatment of infections caused by resistant MRSA and ESBL producing Enterobacter cloacae.

Findings from this study are from in-vitro investigations. Therefore, in-vivo animal studies might be highly valuable to be carried in the future to validate our observations. In addition, we have focused on the activity of WLBU2 against two bacterial strains using MIC and MBC values. However, similar investigations could be conducted for other MDR Gram-positive and Gram-negative bacteria in order to characterize the spectrum of WLBU2 activity with emphasis on WLBU2 activity against biofilm formation. This might be considered under normal conditions and in the presence of salts, serum and proteases. Future experiments might also include exploring the potential synergism between WLBU2 and other cationic AMPs as little is known in this field. Investigations regarding the exact underlying mechanisms of the antibacterial activity of WLBU2 alone and combined with conventional antibiotics might be considered as future experiments. These investigations might involve studies on morphological changes or effects at the molecular level including genes playing role in bacterial resistance, bacterial metabolism or other energetics aspects.

\section{Role of the funding source}

This study was financially supported by the Deanship of Research of Jordan University of Science and Technology [Grant number 20180453].

\section{Acknowledgements}

Many thanks for all staff members of microbiology laboratories at the Jordanian Royal Medical Services for the technical support provided during the study. This work was supported by the Deanship of Research of Jordan University of Science and Technology [Grant number 20180453].

\section{Authors' contributions}

L.E: Conceptualization, Methodology, Validation, Formal analysis, Resources, Writing - Original Draft, Writing Manuscript \& Editing, Supervision, Project administration and Funding acquisition. S.A: Methodology, Validation, Formal analysis, Manuscript Editing and Supervision. A.K: Formal analysis, Investigation, Data Curation and Manuscript Editing. All authors have critically reviewed and approved the final draft and are responsible for the content and similarity index.

\section{Competing interests}

The authors declare no conflict or competing of interests.

\section{Availability of data and materials}

Data of this study are available from the corresponding author on reasonable request.

\section{References}

Abdelbaqi S, Deslouches B, Steckbeck J, Montelaro R, Reed DS (2016). Novel engineered cationic antimicrobial peptides display broad-spectrum activity against Francisella tularensis, Yersinia pestis and Burkholderia pseudomallei. J Med Microbiol 65(2): 188-194. DOI: 10.1099/jmm.0.000209.

Blahová J, Králiková K, Krcméry V, Sr., Schäfer V (1999). Extendedspectrum beta-lactamase producing strains of Enterobacter cloacae transferring resistance to cefotaxime and ceftazidime. J Chemother 11(2): 97-102. DOI: 10.1179/joc.1999.11.2.97.

Chellat MF, Raguž L, Riedl R (2016). Targeting Antibiotic Resistance. Angew Chem 55(23): 6600-6626. DOI: 10.1002/anie.201506818.

Chen C, Deslouches B, Montelaro RC, Di YP (2018). Enhanced efficacy of the engineered antimicrobial peptide WLBU2 via direct airway delivery in a murine model of Pseudomonas aeruginosa pneumonia. Clin Microbiol Infect 24(5): 547.e1-547.e8. DOI: 10.1016/j.cmi.2017.08.029.

Chu H-L, Yu H-Y, Yip B-S, Chih Y-H, Liang Ch-W, Cheng H-T, Cheng J-W (2013). Boosting Salt Resistance of Short Antimicrobial Peptides. Antimicrob Agents Chemother 57(8): 4050-4052. DOI: 10.1128/aac.00252-13.

Clinical and Laboratory Standards Institute (CLSI) (2017). Performance Standards for Antimicrobial Susceptibility Testing. 27th ed. CLSI supplement M100. [online] ]cit. 2020-01-22]. Available from: http://www.iacld.ir/DL/public/96/CLSI-2017.pdf

Coque TM, Baquero F, Canton R (2008). Increasing prevalence of ESBL-producing Enterobacteriaceae in Europe. Euro Surveill 13(47): 19044.

Corbett D, Wise A, Langley T, Skinner K, Trimby E, Birchall S, et al. (2017). Potentiation of Antibiotic Activity by a Novel Cationic Peptide: Potency and Spectrum of Activity of SPR741. Antimicrob Agents Chemother 61(8): e00200-e00217. DOI: 10.1128/ aac.00200-17.

Dadgostar P (2019). Antimicrobial Resistance: Implications and Costs. Infect Drug Resist 12: 3903-3910. DOI: 10.2147/IDR. S234610.

Deslouches B, Clancy C, Nguyen M, et al. (2008). The Antimicrobial Peptide Wlbu2 is Active Against Candida spp., Cryptococcus Neoformans and Leading Causes of Bacterial Sepsis. 48th Annual ICAAC/46th Annual IDSA 2008; abstract No: M-1549. [online[ [cit. 2020-01-22]. Available from: https://www.researchgate.net/ publication/267531044_The_Antimicrobial_Peptide_Wlbu2_is_ Active_Against_Candida_spp_Cryptococcus_Neoformans_and_Leading_Causes_of_Bacterial_Sepsis

Deslouches B, Islam K, Craigo JK, Paranjape SM, Montelaro RC, Mietzner TA (2005a). Activity of the de novo engineered antimicrobial peptide WLBU2 against Pseudomonas aeruginosa in human serum and whole blood: implications for systemic applications. Antimicrob Agents Chemother 49(8): 3208-3216. DOI: 10.1128/AAC.49.8.3208-3216.2005.

Deslouches B, Phadke SM, Lazarevic V, Cascio M, Islam K, Montelaro RC, Mietzner TA (2005b). De novo generation of cationic antimicrobial peptides: influence of length and tryptophan substitution on antimicrobial activity. Antimicrob Agents Chemother 49(1): 316-322. DOI: 10.1128/aac.49.1.316322.2005.

Deslouches B, Steckbeck JD, Craigo JK, Doi Y, Burns JL, Montelaro RC (2015). Engineered cationic antimicrobial peptides to overcome multidrug resistance by ESKAPE pathogens. Antimicrob Agents Chemother 59(2): 1329-1333. DOI: 10.1128/ aac.03937-14.

Deslouches B, Steckbeck JD, Craigo JK, Doi Y, Mietzner TA, Montelaro RC (2013). Rational design of engineered cationic antimicrobial peptides consisting exclusively of arginine and tryptophan, and their activity against multidrug-resistant pathogens. Antimicrob Agents Chemother 57(6): 2511-2521. DOI: 10.1128/aac.02218-12.

Donkor ES, Codjoe FS (2019). Methicillin Resistant Staphylococcus aureus and Extended Spectrum Betalactamase Producing Enterobacteriaceae: A Therapeutic 
Challenge in the 21st Century. Open Microbiol J 13: 94-100. DOI: $10.2174 / 1874285801913010094$.

Ferri M, Ranucci E, Romagnoli P, Giaccone V (2017). Antimicrobial resistance: A global emerging threat to public health systems. Crit Rev Food Sci Nutr 57(13): 2857-2876. DOI: 10.1080/10408398.2015.1077192.

Gopal R, Kim YG, Lee JH, Lee SK, Chae JD, Son BK, et al. (2014). Synergistic Effects and Antibiofilm Properties of Chimeric Peptides against Multidrug-Resistant Acinetobacter baumannii Strains. Antimicrob Agents Chemother 58(3): 1622-1629. DOI: 10.1128/aac.02473-13.

Huang Y, Carroll KC, Cosgrove SE, Tamma PD (2014). Determining the optimal ceftriaxone MIC for triggering extended-spectrum beta-lactamase confirmatory testing. J Clin Microbiol 52(6): 2228-2230. DOI: 10.1128/jcm.00716-14.

Kohn EM, Shirley DJ, Arotsky L, Picciano AM, Ridgway Z, Urban MW, et al. (2018). Role of Cationic Side Chains in the Antimicrobial Activity of C18G. Molecules (Basel, Switzerland) 23(2): 329. DOI: 10.3390/molecules23020329.

Kshetry AO, Pant ND, Bhandari R, Khatri S, Shrestha KL, Upadhaya SK, et al. (2016). Minimum inhibitory concentration of vancomycin to methicillin resistant Staphylococcus aureus isolated from different clinical samples at a tertiary care hospital in Nepal. Antimicrob Resist Infect Control 5(1): 27. DOI: 10.1186/s13756016-0126-3.

Lashua LP, Melvin JA, Deslouches B, Pilewski JM, Montelaro RC, Bomberger JM (2016). Engineered cationic antimicrobial peptide (eCAP) prevents Pseudomonas aeruginosa biofilm growth on airway epithelial cells. J Antimicrob Chemother 71(8): 2200-2207. DOI: 10.1093/jac/dkw143.

Li J, Koh J-J, Liu S, Lakshminarayanan R, Verma CC, Beuerman RW (2017). Membrane Active Antimicrobial Peptides: Translating Mechanistic Insights to Design. Front Neurosci 11: 73. DOI: 10.3389/fnins.2017.00073.

Lin Q, Deslouches B, Montelaro RC, Di YP (2018). Prevention of ESKAPE pathogen biofilm formation by antimicrobial peptides WLBU2 and LL37. Int J Antimicrob Agents 52(5): 667-672. DOI: 10.1016/j.ijantimicag.2018.04.019.

Majidpour A, Fathizadeh S, Afshar M, Rahbar M, Boustanshenas M, Heidarzadeh M, et al. (2017). Dose-Dependent Effects of Common Antibiotics Used to Treat Staphylococcus aureus on Biofilm Formation. Iran J Pathol 12(4): 362-370. DOI: 10.30699/ ijp.2017.27993.

Mandell JB, Deslouches B, Montelaro RC, Shanks RMQ, Doi Y, Urish KL (2017). Elimination of Antibiotic Resistant Surgical Implant Biofilms Using an Engineered Cationic Amphipathic Peptide WLBU2. Sci Rep 7(1): 18098. DOI: 10.1038/s41598-01717780-6.

Mohamed MF, Abdelkhalek A, Seleem MN (2016). Evaluation of short synthetic antimicrobial peptides for treatment of drugresistant and intracellular Staphylococcus aureus. Sci Rep 6(1): 29707. DOI: 10.1038/srep29707.

Mohamed MF, Hamed MI, Panitch A, Seleem MN (2014). Targeting methicillin-resistant Staphylococcus aureus with short saltresistant synthetic peptides. Antimicrob Agents Chemother 58(7): 4113-4122. DOI: 10.1128/aac.02578-14.

Mohammed I, Abass E (2019). Phenotypic detection of Extended Spectrum $\beta$-Lactamases (ESBL) among gram negative uropathogens reveals highly susceptibility to imipenem. Pak J Med Sci 35(4): 1104-1109. DOI: 10.12669/pjms.35.4.207.

Novak KF, Diamond WJ, Kirakodu S, Peyyala R, Anderson KW, Montelaro RC, Mietzner TA (2007). Efficacy of the De NovoDerived Antimicrobial Peptide WLBU2 against Oral Bacteria.
Antimicrob Agents Chemother 51: 1837-1839. DOI: 10.1128/ AAC.00924-06.

Paranjape SM, Lauer TW, Montelaro RC, Mietzner TA, Vij N (2013). Modulation of proinflammatory activity by the engineered cationic antimicrobial peptide WLBU-2. F1000Research 2: 36. DOI: 10.12688/f1000research.2-36.v1.

Prestinaci F, Pezzotti P, Pantosti A (2015). Antimicrobial resistance: a global multifaceted phenomenon. Pathog Glob Health 109: 309-318. DOI: 10.1179/2047773215Y.0000000030.

Rich H, Deslouches B, McHugh KJ, Montelaro R, Robinson KM, Alcorn JF (2016). The Synthetic Antimicrobial Peptide WLBU2 Promotes Staphylococcus aureus Clearance in the Mouse Lung. D32. PNEUMONIA: A6727-A6727. [online] [cit. 2020-01-22]. Available from: https://www.atsjournals.org/doi/abs/10.1164/ajrccmconference.2016.193.1_MeetingAbstracts.A6727

Rooney PJ, O'Leary MC, Loughrey AC, McCalmont M, Smyth B, Donaghy P, et al. (2009). Nursing homes as a reservoir of extended-spectrum beta-lactamase (ESBL)-producing ciprofloxacin-resistant Escherichia coli. J Antimicrob Chemother 64(3): 635-641. DOI: 10.1093/jac/dkp220.

Sani M-A, Separovic F (2016). How Membrane-Active Peptides Get into Lipid Membranes. Acc Chem Res 49(6): 1130-1138. DOI: 10.1021/acs.accounts.6b00074.

Sinha R, Shukla P (2019). Antimicrobial Peptides: Recent Insights on Biotechnological Interventions and Future Perspectives. Protein Pept Lett 26(2): 79-87. DOI: 10.2174/092986652566618102616 0852.

Spanu T, Luzzaro F, Perilli M, Amicosante G, Toniolo A, Fadda G (2002). Occurrence of extended-spectrum beta-lactamases in members of the family Enterobacteriaceae in Italy: implications for resistance to beta-lactams and other antimicrobial drugs. Antimicrob Agents Chemother 46(1): 196-202. DOI: 10.1128/ aac.46.1.196-202.2002.

Stefani S, Goglio A (2010). Methicillin-resistant Staphylococcus aureus: related infections and antibiotic resistance. Int $\mathrm{J}$ Infect Dis 14: S19-S22. DOI: 10.1016/j.ijid.2010.05.009.

Swedan S, Shubair Z, Almaaytah A (2019). Synergism of cationic antimicrobial peptide WLBU2 with antibacterial agents against biofilms of multi-drug resistant Acinetobacter baumannii and Klebsiella pneumoniae. Infect Drug Resist 12: 2019-2030. DOI: 10.2147/idr.s215084.

Tripathi K (2013). Essentials of Medical Pharmacology. 7th ed. Jaypee Brothers Medical Pub., 1002 p.

Turner J, Cho Y, Dinh NN, Waring AJ, Lehrer RI (1998). Activities of LL-37, a cathelin-associated antimicrobial peptide of human neutrophils. Antimicrob Agents Chemother 42(9): 2206-2214. DOI: 10.1128/AAC.42.9.2206.

Tyers M, Wright GD (2019). Drug combinations: a strategy to extend the life of antibiotics in the 21st century. Nat Rev Microbiol 17(3): 141-155. DOI: 10.1038/s41579-018-0141-x.

Wiener ES, Heil EL, Hynicka LM, Johnson JK (2016). Are Fluoroquinolones Appropriate for the Treatment of ExtendedSpectrum $\beta$-Lactamase-Producing Gram-Negative Bacilli? J Pharm Technol 32(1): 16-21. DOI: 10.1177/8755122515599407.

Wu X, Li Z, Li X, Tian Y, Fan Y, Yu C, et al. (2017). Synergistic effects of antimicrobial peptide DP7 combined with antibiotics against multidrug-resistant bacteria. Drug Des Devel Ther 11: 939-946. DOI: $10.2147 /$ dddt.s107195.

Yıldız Ö, Çoban AY, Şener AG, Coşkuner SA, Bayramoğlu G, Güdücüoğlu H, et al. (2014). Antimicrobial susceptibility and resistance mechanisms of methicillin resistant Staphylococcus aureus isolated from 12 Hospitals in Turkey. Ann Clin Microbiol Antimicrob 13: 44. DOI: 10.1186/s12941-014-0044-2. 


\section{Supplementary materials}

Structure:RR-24

Lot NO :P190325-YS181495

Number :0200049

Column :250*4.6mm,Kromasil-C18-5um

Solvent A:0.1\%TFA in $100 \%$ water

Solvent B:0.1\%TFA in 100\%acetonitrile

Gradient :

\begin{tabular}{lcc} 
& A & B \\
$0.1 \mathrm{~min}$ & $73 \%$ & $27 \%$ \\
$25.0 \mathrm{~min}$ & $48 \%$ & $52 \%$ \\
$25.1 \mathrm{~min}$ & $0 \%$ & $100 \%$ \\
$30.0 \mathrm{~min}$ & \multicolumn{2}{c}{ stop }
\end{tabular}

Flow rate: $1.0 \mathrm{ml} / \mathrm{min}$

Wavelength(nm):220

Volume :10ul

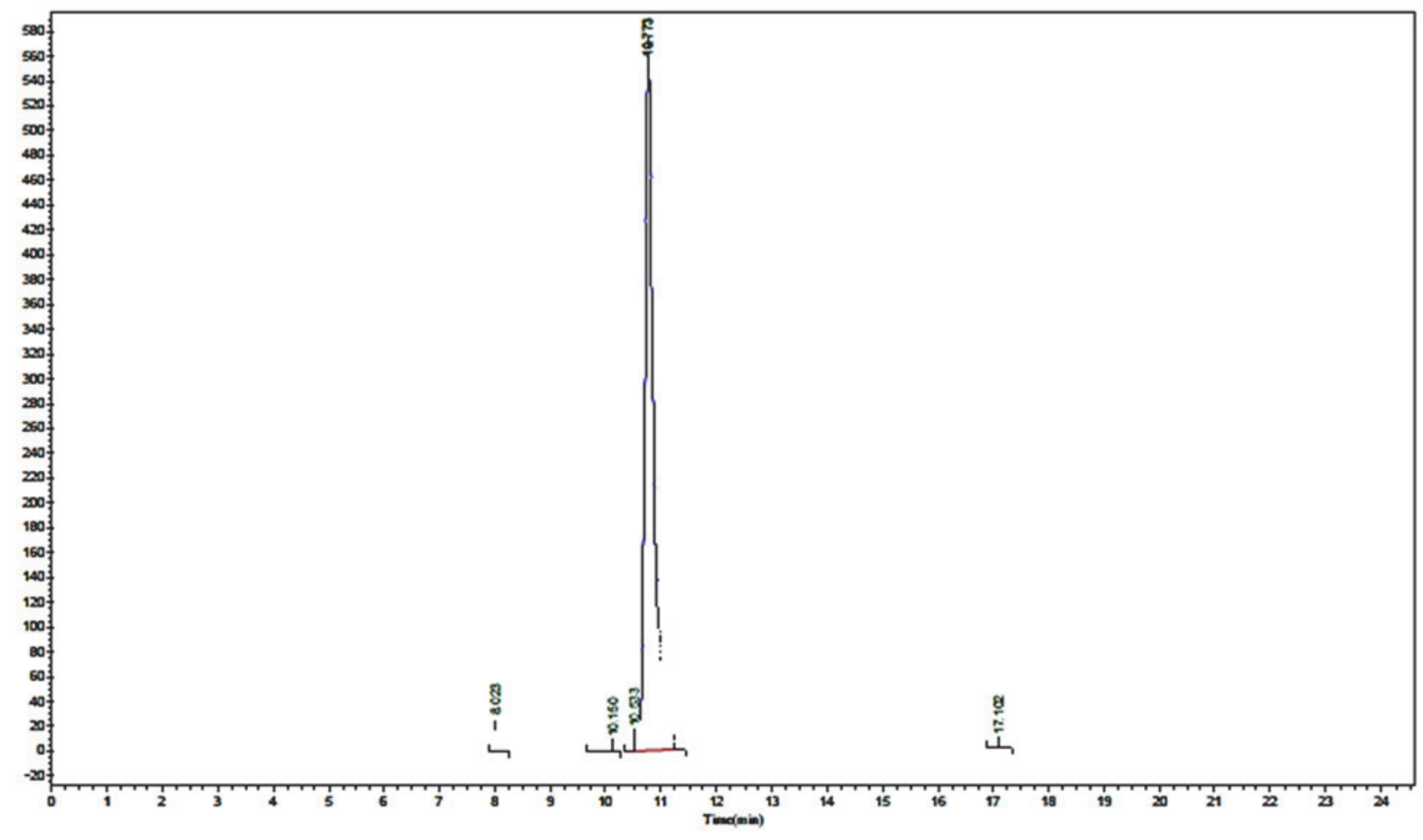

\begin{tabular}{lclll}
\multicolumn{2}{l}{ Peak No. Ret Time } & Height & Area & Conc. \\
1 & 8.023 & 16620.350 & 157764.109 & 2.3592 \\
2 & 10.150 & 1061.782 & 17882.000 & 0.2674 \\
3 & 10.533 & 9412.240 & 49905.289 & 0.7463 \\
4 & 10.773 & 565044.500 & 6428594.500 & 96.1329 \\
5 & 10.773 & 7042.600 & 31414.852 & 0.4698 \\
6 & 17.102 & 109.427 & 1635.794 & 0.0245 \\
\hline Total & & & & 100.00
\end{tabular}

Fig. A. High-performance liquid chromatography (HPLC) information of WLBU2 
MS Spectrum

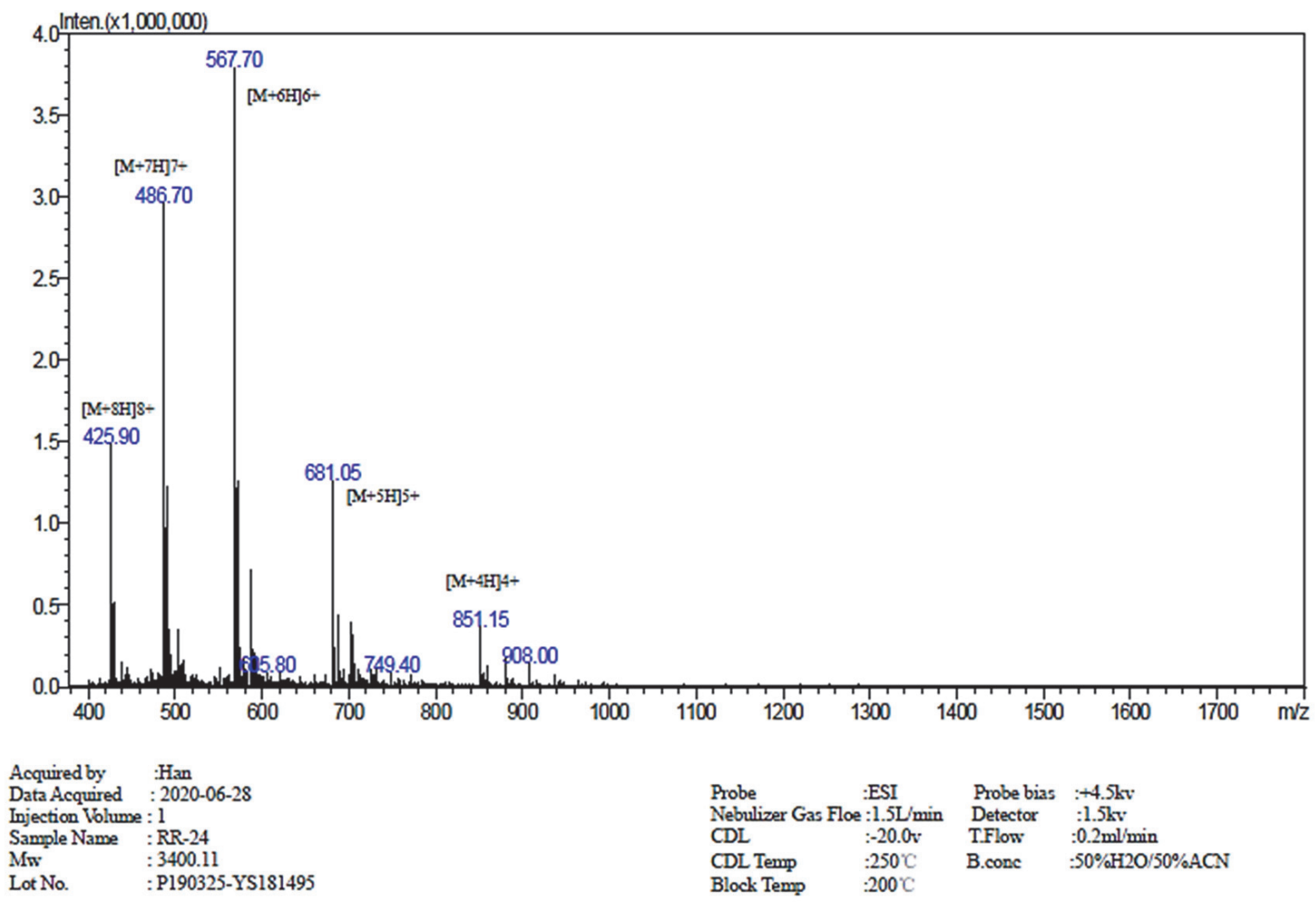

Fig. B. Mass spectrometry (MS) information of WLBU2

Table A. Antibiotic susceptibility based on MIC values ( $\mu \mathrm{g} / \mathrm{ml})$ according to CLSI guidelines (CLSI, 2017)

\begin{tabular}{|c|c|c|c|c|}
\hline Bacteria strain & Antibiotic & Resistant & Intermediate & Sensitive \\
\hline \multirow{3}{*}{ Staphylococcus aureus } & Oxacillin & $\mathrm{MIC} \geq 4$ & - & $\mathrm{MIC} \leq 2$ \\
\hline & Erythromycin & $\mathrm{MIC} \geq 8$ & $\mathrm{MIC}=1-4$ & $\mathrm{MIC} \leq 0.5$ \\
\hline & Vancomycin & $\mathrm{MIC} \geq 16$ & $\mathrm{MIC}=4-8$ & $\mathrm{MIC} \leq 2$ \\
\hline \multirow{4}{*}{ Enterobacter cloacae } & Ceftazidime & $\mathrm{MIC} \geq 16$ & $\mathrm{MIC}=8$ & $\mathrm{MIC} \leq 4$ \\
\hline & Ceftriaxone & $\mathrm{MIC} \geq 4$ & $\mathrm{MIC}=2$ & $\mathrm{MIC} \leq 1$ \\
\hline & Ciprofloxacin & $\mathrm{MIC} \geq 4$ & $\mathrm{MIC}=2$ & $\mathrm{MIC} \leq 1$ \\
\hline & Imipenem & $\mathrm{MIC} \geq 4$ & $\mathrm{MIC}=2$ & $\mathrm{MIC} \leq 1$ \\
\hline
\end{tabular}

